J. Product. \& Dev., 26(4): 955- 970 (2021)

\title{
EFFECT OF LIGHT INTENSITY AND WATER FLOW RATE OF HYDROPONIC UNIT ON THYME (THYMUS VULGARIS L.) PRODUCTION
}

\author{
Nadia F. Mohamed", Essam H. EL_Hanafy," Darwish M. Ibrahim ${ }^{* * *}$ and \\ Ahmed S. Mahmoud* \\ * Water \& Soil Dep., Faculty of Technology \& Development, Zagazig \\ University, Egypt. \\ ** Plant production Dep., Faculty of Technology \& Development, Zagazig \\ University, Egypt. e.mail: nadiafathy15693@gmail.com
}

\section{ABSTRACT}

Hydroponics is a style of cultivation without soil or with growing media, the main aim of the present research is to study the effect of using three different supplemental light intensity treatments (LED light) and four treatments of nutrient (NPK) water flow rates on the Properties of Thymus vulgaris L. plant. The results obtained were compared also with the control (with no supplemental LED light). The light intensities of LED light sources In addition to natural sunlight were: 30,25 and $20 \mu_{\mathrm{mol} \mathrm{m}}^{-2} \mathrm{~s}^{-1}$. The four water flow rates were 20, 15, 10 and $5 \mathrm{l} / \mathrm{h}$. Some properties of Thyme plant were determined as plant length (cm) and the dry weight $(\mathrm{g})$ was measured after measuring fresh weight $(\mathrm{g})$. Also the amount of Photosynthetic pigments and accumulation of essential oil in leaves were determined.

The results showed that, the highest values recorded in thyme plant growth of fresh weight, dry weight and height were $28.7 \mathrm{~g}, 8.4 \mathrm{~g}$ and $36 \mathrm{~cm}$ respectively, at highest light intensity $30 \mu \mathrm{mol} \mathrm{m} \mathrm{m}^{-1}(\mathrm{L1}$.) and middle flow rate $10 \mathrm{l} / \mathrm{h}$ (F3.) the maximum amount of Photosynthetic pigments in leaves were at the middle light intensity $25 \mu \mathrm{mol} \mathrm{m} \mathrm{m}^{-1}$ (L2.) and middle flow rate $10 \mathrm{l} / \mathrm{h}$ (F3.) where chlorophyll $A, B$, total chlorophyll and carotenoids were $4.55,2,6.57$ and $2.32 \mathrm{mg} / \mathrm{g}$ respectively. It is clearly observed that the highest accumulate of essential oil was4.66 \% at the highest light intensity $30 \mathrm{\mu mol} \mathrm{m}^{-2} \mathrm{~s}^{-1}(\mathrm{L1}$.) and middle flow rate $10 \mathrm{l} / \mathrm{h}$ (F3.), when compared with the rest of treatments.

Conclusively, from these results it could be concluded that light intensity and water flow rate have great effect on productivity of thyme plant under Hydroponic system.

Keywords: Hydroponics, Thymus vulgaris L. , LED light, water flow rates, NPK, growth \& yield, Photosynthetic pigments, essential oil. 


\section{INTRODUCTION}

Conventional agriculture faces major challenges, the most important of which is the depletion of soil productivity in cultivable areas, poor soil fertility due to continuous cultivation over the years, and most importantly reduce capital and availability, (Lambin, 2012; Lal, 2015 and Lehman et al., 2015). In addition to threats from climate change represented by rising temperatures, frequent droughts, and unpredictability of climate patterns; poor management of water resources, which leads to wasting a lot amount of water, unchecked pollution of water bodies and low levels of groundwater (St.Clair and Lynch, 2010; Dhawan, 2017 and Bhanja et al., 2018). Nowadays, these challenges pose a serious threat to traditional farming systems for which food production has become a real challenge. Therefore, the efficiency of traditional agricultural practices must be raised to improve water saving, productivity and environmental sustainability (Lambin and Meyfroidt, 2011). Modern forms of agriculture must include solutions to low soil productivity, depleted soil nutrient reserves, and limited water availability, as well as help meet the challenges of climate change. Hydroponics is a style of cultivation without soil or with growing media, which only uses water or materials that supporting plants roots that provide nutrients for the growth of crops. It is preferable to use it in greenhouses to give plants a distinct and controlled environment for growth, in addition to reducing the use of pesticides, taking into account the needs of plant growth, improving crop yields and production efficiency, the possibility of planting plants throughout the year compared to traditional agriculture.

Hydroponic systems reduced growing period, requires less space, and plants can be produced anywhere, in a small spaces. This system is ideal when outdoor gardening space is limited. On the other hand, Hydroponic offer many advantages such as: a reduction of labor requirements, a lower water requirement, increased productivity, uniform plant production, the possibility of cultivation at any time of the year, rapid economic return, and high quality products. In recent years, the development of light-emitting diode (LED) technology has enabled low-cost indoor cultivation using artificial light to enable plant production in places that are unsuitable for crop growth. Light influences the morphological and physiological processes in plants (Humbert et al., 2007). When plants are exposed to low light intensity, the leaf surface area increases and is rectangular, and the height of the plant increases (Setiawati et al., 2018 and Rezai et al., 2018). High light intensity can induce plants to produce high starch and carbohydrate contents, which contribute positively to their biomass (K€ose, 2014). In legumes, growth, nutrient uptake and use-efficiency ratios were higher at higher Photosynthetic 
Photon Flux Density (PPFD) than at lower PPFD. However, when plants are simultaneously exposed to more than one stress factor, the responses are more complex (Baligar et al., 2006). For instance, it was observed that shading alleviated the negative impact of drought on leaf traits and biomass characteristics of Acer buergerianum Miq (Guo et al., 2013). In hydroponic cultivation, foldable nutrient solution cultivation substrates also allow nutrients to be transported to the root surfaces via turbulent diffusion (Baiyin et al., 2021a), which transfers nutrient ions to the root surface by the irregular motion of fluid particles.

Recently, various researchers have investigated the effect of nutrient solution flow rate on crop growth. Dalastra et al., (2020) compared different nutrient solution flow rates of $0.5,1.0,2.0$, and $4.01 / \mathrm{min}$ applied to separate cultivation channels hydroponic lettuce and found that in the plant shoots, with the highest lettuce yield obtained at a nutrient solution flow rate of $1.0 \mathrm{1} / \mathrm{min}$. (Genuncio et al., 2012) compared between different lettuce varieties (Lucy, Izabela, and Veneza) grown at different flow rates $(0.75,1.0$, and $1.501 / \mathrm{min})$ and nutrient ion concentrations (the $50 \%, 75 \%$, and $100 \%$ concentration of the standard nutrient solution). And showed that nutrient solution with a flow rate of $1.5 \mathrm{l} / \mathrm{min}$ and $100 \%$ ionic concentration increased the fresh weight of Izabella and Venae lettuce varieties. The use of plants in medicine is reported since the origin of human civilizations, the consumption of herbal products in the more affluent countries has increased in the past decades. In Europe, Germany is the country with the highest share of the herbal medicines market and it was reported that the sales of herbal medicinal products (HMPs) in 1997 were 1.8 billion US\$ (Phillipson, 2007). Medicinal plants can be used in the form of crude drugs such as teas, tinctures, powders, poultices and infusions, as well as other formulations (Balunas and Kinghorn, 2005).

Herbal treatments are still the most popular form of traditional medicine, and are highly lucrative in the international marketplace. Medicinal plants play a vital role in disease prevention and treatment. In this regard, entire plants or specific parts of medicinal plants can be used for medicinal purposes, which in China is referred to as traditional Chinese medicine. Alternatively, they can be used as raw materials in the pharmaceutical industry. According to the World Health Organization (WHO), more than $80 \%$ of the world's population routinely uses traditional medicines to meet primary healthcare needs (WHO, 2019). Thymus vulgaris L. belongs to the Lamiaceae family and consists of over 400 species of herbaceous annuals and perennial plants that are extensively used, for medicinal and no medicinal purposes. These plants are widely distributed 
throughout the Old World (Ozudogru et al., 2011).Thymus contains thymol as the main component. This phytochemical is recognized for its antibacterial and antifungal activity, thus this plant is used industrially in the preparation of human disinfectants, mouthwashes and other antimicrobial agents used at home (RuedaPuente et al., 2018).

Therefore, the objective of the present study was to evaluate the effect of light intensity and water flow rates on productivity of Thymus vulgaris L. under hydroponic system.

\section{MATERIALS AND METHODS}

\section{Materials}

The present study was conducted at faculty of technology and development zagazig university Egypt. The experiment was carried out through the period from $10^{\text {th }}$ March 2021 to $20^{\text {th }}$ May 2021 to find out the effect of using supplemental LED light $\left([\mathrm{L}] \mu \mathrm{mol} \mathrm{m} \mathrm{m}^{-2} \mathrm{~s}^{-1}\right)$ and water flow rates $([\mathrm{F}] \mathrm{l} / \mathrm{h})$ on the efficiency of Thymus vulgaris $\mathrm{L}$ yield. The results obtained were compared also with the control treatment (with no supplemental LED light). Experiment was executed on Vermiculite soil, the soil properties were Ec $2.04 \mathrm{ds} \mathrm{m}^{-1}$ and $\mathrm{pH}$ 6.6. The water properties were $\mathrm{Ec} 0.3 \mathrm{ds} \mathrm{m}^{-1}$ and $\mathrm{pH}$ 7.2.

\subsection{Plant}

Thyme (Thymus vulgaris L.) plant was sown manually on $10^{\text {th }}$ March 2021 , while harvesting was occurred on the $20^{\text {th }}$ May 2021. Fertilizer needs for Thyme plant was added weekly with $100 \mathrm{ml}$ of a 20-20-20\% $(\mathrm{v} / \mathrm{v}) \mathrm{NPK}$ nutrient solution. The average temperatures in hydroponic unit were between $26-37^{\circ} \mathrm{C}$ and Average humidity between $10-50 \%$.

\subsection{Lighting Systems and Irradiance Measurements}

Three different treatments of supplemental LED light (light emitting diode) were horizontally mounted onto given wood frames $120 \mathrm{~cm}$ above hydroponic unit, resulting in distances between the bottom of the LED light sources and the glass greenhouse channels of $90 \mathrm{~cm}$. The power of three different light treatments: 18, 9 and 5 watt . The light intensities of LED light sources In addition to natural sunlight were: 30,25 and $20 \mu \mathrm{mol} \mathrm{m} \mathrm{s}^{-1}$ from L1 to L3 respectively and the light intensity of natural sunlight only was $18 \mu \mathrm{mol} \mathrm{m} \mathrm{m}^{-2} \mathrm{~s}^{-1}$.

The measurements of the light intensity were taken by Light Meter (UT383 Mini Light Meter, Uni-Trend Technology, China). Plants were exposed to an average of $2 \mathrm{~h}$ of sunshine per day during the experiment. In addition to the natural 
sunlight, plants were subjected to supplemental lighting from 6:00 a.m. to 8:00 p.m. for a photoperiod of $14 \mathrm{~h}$ per day during the glass greenhouse experiment. Plastic sheeting extending from above the light fixtures to below the hydroponic unit eliminated neighboring light pollution.

\subsection{Hydroponic system and Measurements}

The NFT system consists of channels which nutrient solution is pumped from a supply tank through an inlet to channels where seedling there and then is returned back into the supply tank. The channels have holes in the top where plastic pots filled with vermiculite soil and young thyme plants. Nutrient solution was applied in irrigations system through a flow water system. The length of channels was ( $3 \mathrm{~m}$ ) and the four water flow rates were 20,15, 10 and $5 \mathrm{l} / \mathrm{h}$ from F1 to F4 respectively. They were applied with intermittent flow (half hour "on" and two and a half hours "off"). Channels were $35 \mathrm{~cm}$ diameter and stand $120 \mathrm{~cm}$ high above the ground with row Spacing of $15 \mathrm{~cm}$.

\section{Methods}

\subsection{Experimental setup}

The experiment was with three replications and carried out under the following variables as shown in Figure.1.

-Three different supplemental light intensity treatments (LED light), compared to without LED light (Control).

-Four treatments of water flow rates.

\subsection{Measurements}

The following measurements were done to evaluate the effect of previous experimental parameters as:

\subsubsection{Plant and its components}

All 48 experimental thyme plants were harvested separately of each treatment from above-ground .Some properties of Thyme plant were determined as plant length $(\mathrm{cm})$ and the dry weight was measured after measured fresh weight $(\mathrm{g})$. The plants were oven dried at $70^{\circ} \mathrm{C}$ until constant weight was reached.

\subsubsection{Photosynthetic pigments}

Carotenoids were extracted from the fragments of ray florets of the Weight of $100 \mathrm{mg}$ with concentrated acetone $(10 \mathrm{ml})$. The absorbance was measured at the wave length of $440 \mathrm{~nm}$ for carotenoids. The concentration of the total 


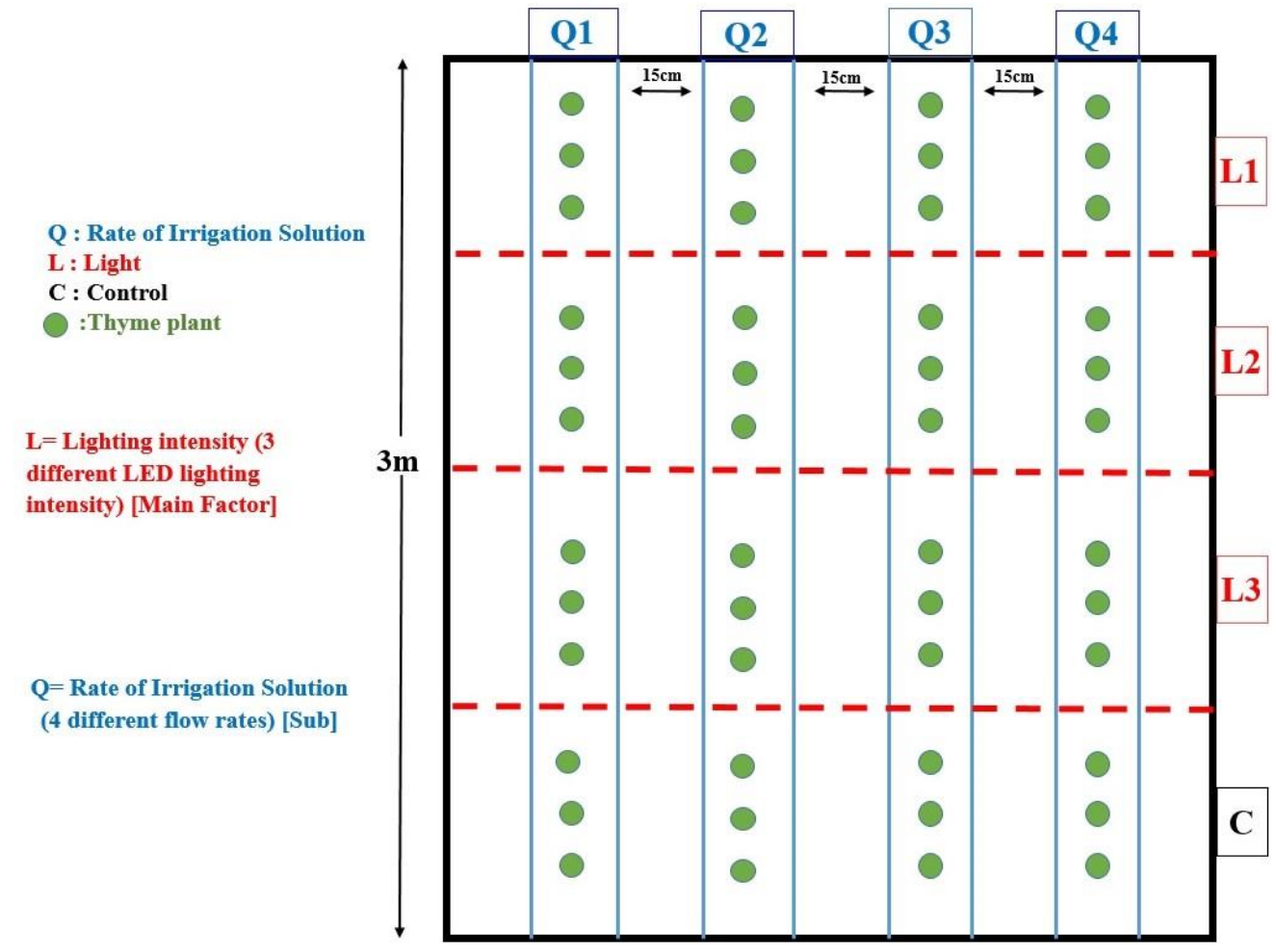

Fig.1. Schematic of the used NFT and LED light systems

carotenoids was calculated according to the formula (Wettstein, 1957):

$\mathrm{C}_{\mathrm{K}}=4.695 \times \mathrm{A} 440(\mathrm{mg} / \mathrm{g})$

A440 - absorbance at $\lambda=440 \mathrm{~nm}$

Chlorophylls were extracted from the tissues of leaves (the first fully developed leaf under the inflorescence was sampled) of the weight of $100 \mathrm{mg}$, with concentrated acetone $(10 \mathrm{ml})$. Absorbance was measured at adequate wavelengths characteristic for chlorophyll a, b and Total chlorophyll respectively 645 and $663 \mathrm{~nm}$. The concentration of chlorophyll a, b and Total chlorophyll was calculated according to the formulae (Wettstein, 1957):

$\mathrm{C}_{\mathrm{a}}=12.7 \times \mathrm{A} 663-2.7 \times \mathrm{A} 645(\mathrm{mg} / \mathrm{g})$

$\mathrm{C}_{\mathrm{b}}=22.9 \times \mathrm{A} 645-4.7 \times \mathrm{A} 663(\mathrm{mg} / \mathrm{g})$

Total C $=7.12 \times \mathrm{A} 663+16.8 \times \mathrm{A} 645(\mathrm{mg} / \mathrm{g})$

A645 - absorbance at $\lambda=645 \mathrm{~nm}$

A663 - absorbance at $\lambda=663 \mathrm{~nm}$

Samples were determined by the spectrophotometer. 


\subsubsection{Percentage of Essential oil}

Essential oil was extracted with a weight of $2 \mathrm{~g}$ of the finely ground sample. The samples were wrapped in filter paper and tied well with a thread. The samples were dried in an electric oven at $70^{\circ} \mathrm{C}$. , Then soaked in ether solution for 12 hours. After that samples were placed in a Soxhlet unit with ether solution for 6 hours. The samples were first dried by air, then dried in an electric oven at $70^{\circ} \mathrm{C}$. . Samples were weighed after drying.

Essential oil was calculated according to the formulae:

\% of Essential oil = $($ Sample weight before soaking - Sample weight after soaking) x 100

Essential oil was extracted according to Luque and García-Ayuso (1998).

\section{RESULTS AND DISCUSSION}

\section{Plant growth:}

Data at Figure (2) show the effect of different levels of light intensity and flow rates on fresh, dry weight and height of thyme plant the highest values recorded of fresh weight, dry weight and height of thyme plant were $28.7 \mathrm{~g}, 8.4 \mathrm{~g}$ and $36 \mathrm{~cm}$ respectively at highest light intensity $30 \mu \mathrm{mol} \mathrm{m} \mathrm{m}^{-2} \mathrm{~s}^{-1} \quad$ (L1.) and middle flow rate $10 \mathrm{l} / \mathrm{h}$ (F3.) Compared to other treatments, while the lowest values of fresh weight, dry weight and height of plant were $16.3 \mathrm{~g}, 3.2 \mathrm{~g}$, and 22 $\mathrm{cm}$ respectively at control. The obtained results are found to be agreed with the following findings, Nguyen et al., (2019) showed that The Spinacia oleracea L. Plant height increased with increasing light intensity.That plant height of spinach was higher in $\left(226 \mu \mathrm{mol} \mathrm{m} \mathrm{s}^{-2}\right)$ and $\left(183 \mu \mathrm{mol} \mathrm{m} \mathrm{m}^{-2}\right)$ than in $\left(90 \mu \mathrm{mol} \mathrm{m} \mathrm{s}^{-2}\right)$ and $\left(140 \mu \mathrm{mol} \mathrm{m} \mathrm{m}^{-1}\right)$.Khater and Ali (2015) reported that the ideal flow rate has positive effect on lettuce production under hydroponics. They also reported that the nutrients' uptake got decreased with increased flow rate and this negatively affected the fresh weight of plant. The other finding of Khater and Ali (2015) is that increase of flow rate lead to decrease of accumulation of nutrients in the root zone of hydroponic system. Water movement in the system and the rate of turnover should be designed to ensure good contact time for roots and water flow in the system. Baiyin et al., (2021b) found that Beta vulgaris L. growth was promoted by flow rates ranging from $2 \mathrm{~L} / \mathrm{min}$ to $4 \mathrm{~L} / \mathrm{min}$, and a flow rate of 4 $\mathrm{L} / \mathrm{min}$ optimized the maximum plant yield. Beyond this optimal flow rate, the plant yield decreased on flow rates 6 and $81 / \mathrm{min}$. directly it is observed the effects 


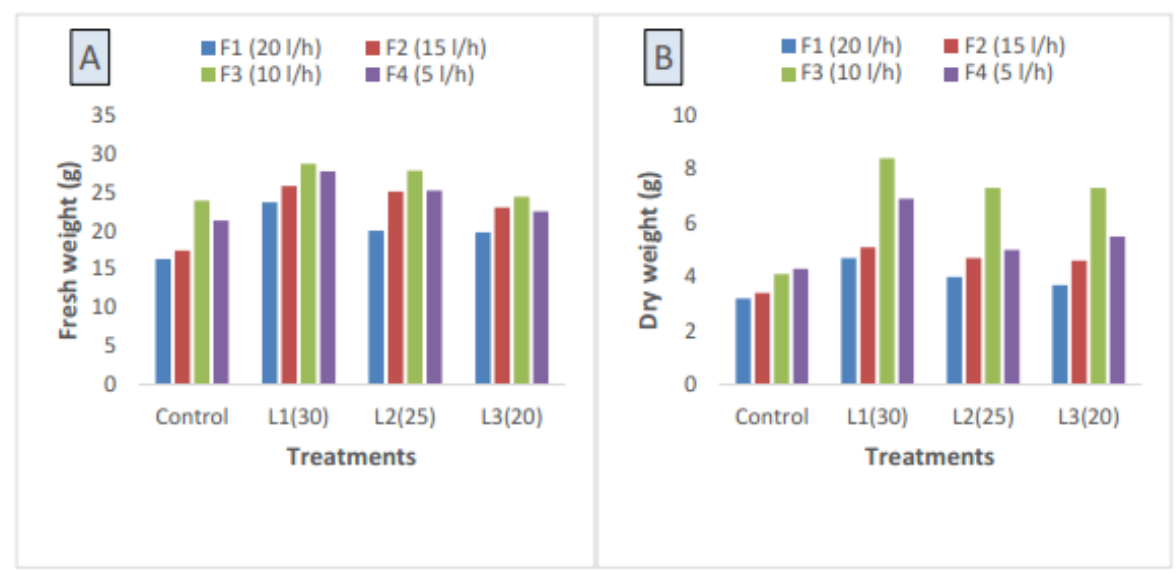

Fig (2): Effect of light intensity and water flow rate on thyme growth; (A): Fresh weight (g). (B) Dry weight (g). (C): Plant height (cm).

of flow rate on plant growth as seen by the plant growth indexes of dry weight and fresh weight. NPK fertilizer along with a special LED light produced the highest basil yield (Barbi et al., 2021).

\section{Photosynthetic pigments:}

It is clearly observed According to Figure (3) that the maximum amount of Photosynthetic pigments in leaves were at the middle light intensity $25 \mu \mathrm{mol}$ $\mathrm{m}^{-2} \mathrm{~s}^{-1}$ (L2.) and middle flow rate $10 \mathrm{l} / \mathrm{h}$ (F3.) where chlorophyll A, B, total chlorophyll and carotenoids were $4.55,2,6.57$ and $2.32 \mathrm{mg} / \mathrm{g}$ respectively, comparing with other treatments. (Nguyen et al., 2019). The chlorophyll A and total chlorophy 11 contents in Spinacia oleracea L. were significantly higher in 

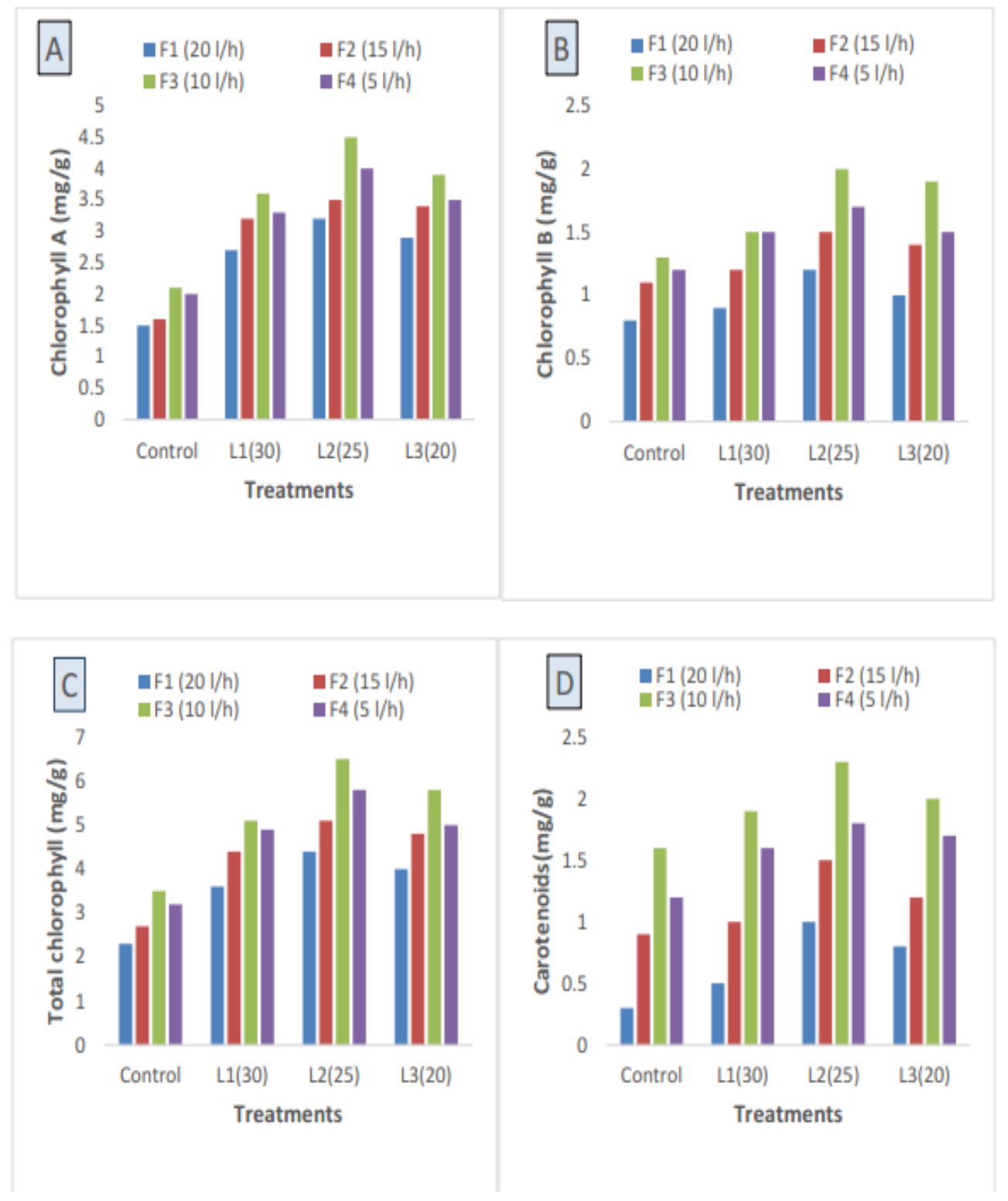

Fig (3): Photosynthetic pigments in thyme leaves; (A): Chlorophyll A (mg/g). (B) Chlorophyll B (mg/g). (C): Total chlorophyll (mg/g). (D): Carotenoids (mg/g). 
medium light intensity I3 $\left(183 \mu \mathrm{mol} \mathrm{m} \mathrm{m}^{-2} \mathrm{~s}^{-1}\right)$ treatment than in I1 90 ( $\mu \mathrm{mol}$ $\left.\mathrm{m}^{-2} \mathrm{~s}^{-1}\right)$, I2. $140\left(\mu \mathrm{mol} \mathrm{m} \mathrm{s}^{-2}\right)$ and I4 $\left(240 \mu \mathrm{mol} \mathrm{m} \mathrm{m}^{-2} \mathrm{~s}^{-1}\right)$ treatments. NPK by $100 \mathrm{~kg} / \mathrm{ha}$ dose increased the chlorophyll content on Arachis hypogaea L. leaves with an increase of $0.540 \mathrm{mg} / \mathrm{g}$. This result was significantly different from NPK under the doses of 25, 50 and $75 \mathrm{~kg} / \mathrm{ha}$. (Purbajanti et al.,2019).

Similar experiment was conducted in peanut at seedling stage, the chlorophyll content in the seedling stage increased with the increase of the peanut biochar-based fertilizer application (Li et al., 2017). Another similar result also be found in maize and sorghum plants (Amujoyegbe et al., 2007). And in soybean (Ghosh et al., 2004), total chlorophyll content was increased by increasing dosage of fertilizer. The leaf is the most important organ for plants to transfer light energy to chemical energy by means of photosynthesis. Photosynthetic capacity is closely related to plant growth (Goudriaan et al., 1985).

\section{Essential oil:}

Figure (4) presents the comparison of essential oil accumulation in percentage $(\%)$ in thyme leaves with different light intensity and water flow rates. From the evaluation of the graph, it is clearly observed that the ideal treatment was at highest light intensity $30 \mu \mathrm{mol} \mathrm{m}^{-2} \mathrm{~s}^{-1}$ (L1.) and middle flow rate $10 \mathrm{l} / \mathrm{h}(\mathrm{F} 3$.) with the highest accumulated essential oil $4.66 \%$ followed by $3.86 \%$ and $3.74 \%$ of accumulated essential oil at highest light intensity $30 \mu \mathrm{mol} \mathrm{m} \mathrm{m}^{-2} \mathrm{~s}^{-1}$ (L1.), lowest flow rate $5 \mathrm{l} / \mathrm{h}(\mathrm{F} 4$.) and light intensity $25 \mu \mathrm{mol} \mathrm{m}^{-2} \mathrm{~s}^{-1}$ (L2.), middle flow rate $10 \mathrm{l} / \mathrm{h}$ (F3.) respectively When compared with the rest of treatments.

Wang et al., 2020 observed that the essential oil yield was proportional to the light irradiation the highest oil yield $(1.86 \%)$ was obtained in plants grown in $100 \%$ full sunlight, while the lowest oil yield $(1.30 \%)$ was obtained from plants grown in $12 \%$ full sunlight.

This result shows that high light intensity promotes biosynthesis of essential oil in A. heterotropoides var. mandshuricum. Omidbaigi and Arjmandi (2002) suggested that the use of nitrogen and phosphorous fertilizers increased the yield and influenced the essential oil components in thyme (Thymus vulgaris L). Alizadeh et al., (2010) using complete fertilizer up to $1500 \mathrm{mg} / \mathrm{plant}$ induced increase in the essential oil percentage in Satureja hortensis L. The highest value of essential oil 


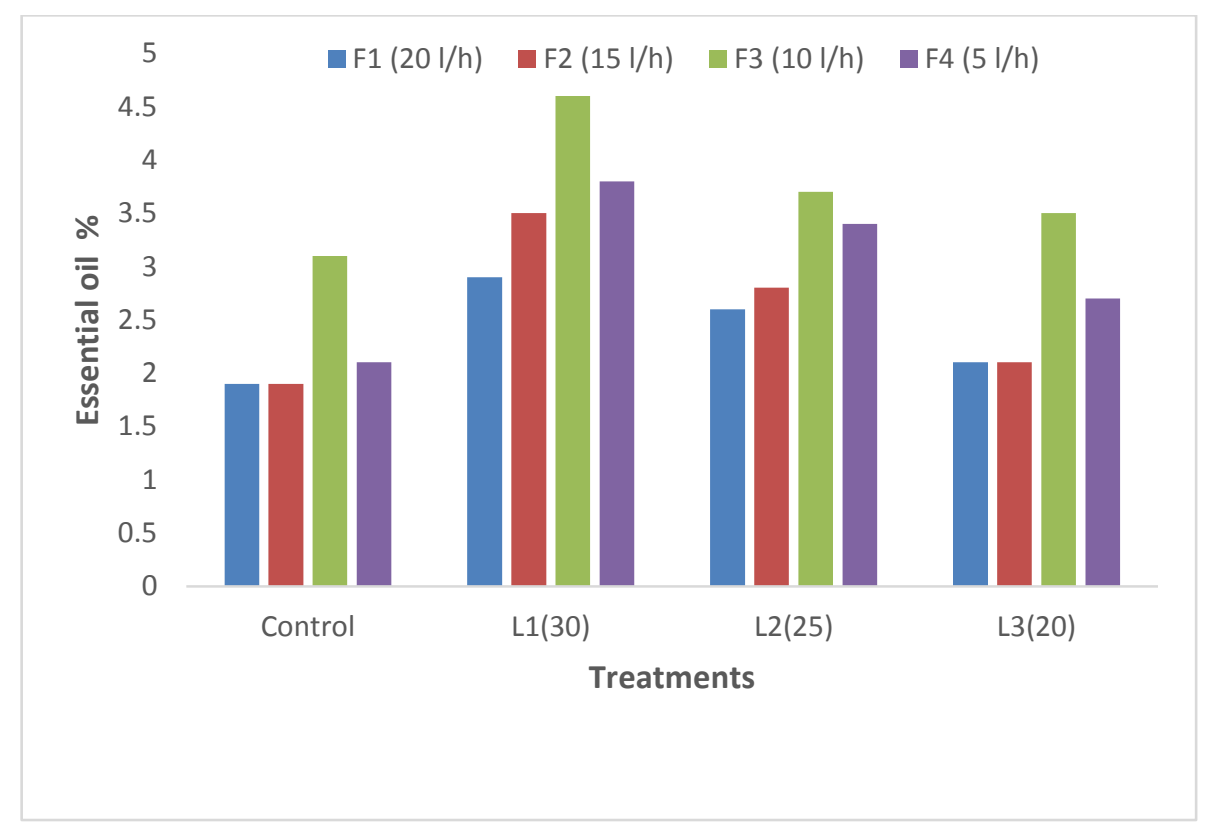

Fig 4: Essential oil accumulation in thyme leaves with different light intensity and water flow rates.

percentage $(2.81 \%)$ was observed from the treatment of $1500 \mathrm{mg} / \mathrm{plant}$ compared with control (1.82\%) treatment. Results in Figure (2) showed that the increase in the biomass of the plant is due to the increased exposure to nutrients. The increase in the biomass increases essential oil accumulation in the plant as found in Figure (4).

Conclusively, from these results it could be concluded that light intensity and water flow rate under hydroponic system have a major role in increasing the productivity of thyme plant by increasing the fresh and dry weight, also the height of the plant, as well as increasing the Essential oil accumulation and chlorophyll content in leaves.

\section{REFERENCES}

Alizadeh, A; M. Khoshkhui, K. Javidnia, O. Firuzi, E. Tafazoli and A. Khalighi (2010).Effects of fertilizer on yield, essential oil Composition, total phenolic content and antioxidant activity in Satureja hortensis L. (Lamiaceae) cultivated in Iran. Journal medicinal Plants Res. 4:033-040. 
Amujoyegbe, B. J; J. T. Opabode and A. Olayinka (2007). African Journal of Biotechnology 6 1869-73.

Baiyin, B; K. Tagawa, M. Yamada, X. Wang, S. Yamada, S. Yamamoto and Y. Ibaraki (2021a). Effect of the Flow Rate on Plant Growth and Flow Visualization of Nutrient Solution in Hydroponics. Horticulture, 7: 225. [Cross Ref].

Baiyin, B; K. Tagawa, M. Yamada, X. Wang, S. Yamada, Y. Shao, P. An, S. Yamamoto and Y. Ibaraki (2021b). Effect of Nutrient Solution Flow Rate on Hydroponic Plant Growth and Root Morphology. Plants. 10(9):1840. https://doi.org/ 10.3390/ plants 10091840.

Baligar, V.C; N.K. Fageria, A.Q. Paiva, A. Silveira, A.W.V. Pomella and R. Machado (2006). Light intensity effects on growth and micronutrient uptake by tropical legume cover crops. Journal. Plant Nutrition. 29 (11), 1959-1974.

Balunas, M. J. and A. D.Kinghorn (2005). Drug discovery from medicinal plants. Life Sci. 78, 431-441.

Barbi, S; F. Barbieri, A. Bertacchini, L. Barbieri and M. Montorsi (2021). Effects of Different LED Light Recipes and NPK Fertilizers on Basil Cultivation for Automated and Integrated Horticulture. Methods. Appl. Sci., 11 (6): 2497. https://doi.org/ 10.3390/ app 11062497.

Bhanja, S.N; A. Mukherjee and M. Rodell (2018). Groundwater storage variations in India. Groundwater of South Asia. Springer, Singapore, pp. 49-59. https://doi.org/ 10.1007/978-981-10-3889-1_4.

Dalastra, C. M; M.R. da Silva, T.A. Nogueira and G.C. Fernandes (2020). Head Lettuce Production and Nutrition in Relation to Nutrient Solution Flow. Hortic. Bras. 38, 21-26. [CrossRef].

Dhawan, V. (2017). Water and agriculture in India: background paper for the South Asia expert panel during the Global Forum for Food and Agriculture (GFFA). OAV - German Asia-Pacific Business Association within the Frame of the Bilateral Cooperation Project on the Development of International Cooperation with Asia, co-funded by the Federal Ministry of Food and Agriculture (BMEL).

Genuncio, G.d; A.C. Ferrari, N. Majerowicz and E. Zonta(2012). Hydroponic Lettuce Production in Different Concentrations and Flow Rates of Nutrient Solution. Hortic. Bras. 30, 526-530. [CrossRef]. 
Ghosh, P. K; K. K. Bandyopadhyay, M. C. Manna, K. G. Mandal, A. K. Misra and K. M .Hati (2004). Bioresource Technology 95 85-93.

Goudriaan, J; Van H.H. Laar, H. Van Keulen and W. Louwerse (1985).Photosynthesis, CO2 and Plant Production. In Wheat Growth and Modelling. Springer: Boston, MA, USA, pp. 107-122.

Guo, X; W. Guo, Y. Luo, X. Tan, N. Du and R. Wang (2013). Morphological and biomass characteristic acclimation of trident maple (Acer buergerianum Miq.) in response to light and water stress. Acta Physiol. Plant. 35, 1149-1159.

Humbert, L; D. Gagnon, D. Kneeshow and C. Messier (2007). A shade tolerance index for common understory species of northeastern North America. Ecol. Indicate. 7 (1), 195-207.

K€ose, B. (2014). Effect of light intensity and temperature on growth and quality parameters of grafted vines. Not. Bot. Horti Agrobot. ClujNapoca 42, 507-515.

Khater, E. S. G; and S. A. Ali (2015). Effect of flow rate and length of gully on lettuce plants in aquaponic and hydroponic systems. Journal of Aquaculture Research \& Development, 6(3), 1.

Lal, R. (2015). Restoring soil quality to mitigate soil degradation. Sustain 7, 5875-5895. https://doi.org/10.3390/su7055875.

Lambin, E.F. (2012). Global land availability: Malthus versus Ricardo. Glob. Food Secur.83-87. https://doi.org/10.1016/j.gfs.2012.11.002.

Lambin, E.F. and P. Meyfroidt (2011). Global land use change, economic globalization, and the looming land scarcity. Proc. Natl. Acad. Sci. U. S. A. 108, 3465-3472. https://do i.org/10.1073/pnas.1100480108.

Lehman, R.M; C.A.Cambardella, D.E. Stott, V. Acosta-Martinez, D.K. Manter, J.S. Buyer, J.E. Maul, J.L. Smith, H.P. Collins, J.J. Halvorson, R.J. Kremer, J.G. Lundgren, T.F. Ducey, V.L. Jin and D.L. Karlen (2015). Understanding and enhancing soil biological health: the solution for reversing soil degradation. Sustain 7, 988-1027. https://doi.org/10.3390/su7010988.

Li, Y; N. Li, P. Luo, Y. Wang, J. Dai and J. Yang (2017). IOP Conf. Series: Materials Science andEngineering 274.

Luque de Castro, M. D. and L. E. García-Ayuso (1998). Soxhlet extraction of solid materials: an outdated technique with a promising innovative future. Journal of Analytica Chimica Acta, 369(1-2):1-10. 
Nguyen, T. P. D., T. T. H. Tran and Q. T. Nguyen (2019). Effects of light intensity on the growth, photosynthesis and leaf microstructure of hydroponic cultivated spinach (Spinacia oleracea L.) under a combination of red and blue LEDs in house. International Journal of Agricultural Technology,. Vol. 15(1): 75-90.

Omidbaigiand, A. and Arjmandi (2002). Effects of NP Supply on Growth, Development, Yield and Active Substances of Garden Thyme (Thymus vulgaris L.). Acta Hort. 576, ISHS.

Ozudogru, E.A; E. Kaya and E. Kirdok (2011). Development of protocols for short, medium and long term conservation of thyme. Acta Horticulturae, 918, pp. 43-50.

Phillipson, J. D. (2007). Phytochemistry and pharmacognosy. Phytochemistry. 68: 2960-2972.

Purbajanti, E. D; W. Slamet, E. Fuskhah and Rosyida (2019). Effects of organic and inorganic fertilizers on growth, activity of nitrate reductase and chlorophyll contents of peanuts (Arachis hypogaea L.). IOP Conf. Ser.: Earth Environ. Sci. 250: 012-048.

Rezai, S; N. Etemadi, A. Nikbakht, M. Yousefi and M.M. Majidi (2018). Effect of light intensity on leaf morphology, photosynthetic capacity, and chlorophyll content in sage (Salvia officinalis L.). Journal of Horticultural Science and Technology. 36 (1), 46-57.

Rueda-Puente, E.O; J.J. Juvera Bracamontes, I.G. Romo López and R.J. Holguín Peña (2018). Evaluación de la actividad antibacteriana in vitro de aceites esenciales de orégano y tomillo contra Ralstonia solanacearum. Revista mexicana de ciencias agrícolas 9(SPE20): 4251-4261.

Setiawati, T; A. Ayalla, M.A. Nurzama and Z. Mutaqin (2018). Influence of light intensity on leaf photosynthetic traits and alkaloid content of Kiasahan (Tetracera scandens L.). IOP Conf. Ser. Earth Environ. Sci. 166, 12-25.

St. Clair, S.B. and J.P. Lynch (2010). The opening of Pandora's Box: climate change impacts on soil fertility and crop nutrition in developing countries. Plant Soil, 335: 101-115. https:// doi.org/ 10.1007 / s11104-010-0328-z.

Wang, Z; S. Xiao, Y. Wang, J. Liu, H. Ma, Y. Wang and et al., (2020). Effects of light irradiation on essential oil biosynthesis in the medicinal plant Asarum heterotropoides Fr. Schmidt var. mandshuricum (Maxim) Kitag. PLoS ONE 15(9): e0237952. 
Wettstein, D. (1957). Chlorophyll - letale und der submikroskopische Formwechsel der Plastiden.Exp. Cell Res. , 12: 427-487.

World Health Organization (2019). Neglected Tropical Diseases.Available online:https://web.archive.org/web/20140227152033/; http://www. who. int/ neglecteddiseases /en.

تأثير شدة الإضاعة ومعدل تدفق المياه على إنتاجية وحدة الزراعة المائيه من (Thymus vulgaris L.)

"نادية فتحي محمد ، “عصام حسني الحنفي ، "درويش محمد إبراهيم ،"أحمد الثربيني محمود *قنم علوم الأر اضي و المياه، كلية التكنولوجياو التنمية، جامعة الزقازيق، مصر. ** قسم الإنتاج النباتي، كلية التكنولوجيا والتنمية، جامعة الزقازيق، مصر.

الزراعة المائية هي اسلوب زراعة بدون تربة أو بوسائط نمو ، والتي التي التئي

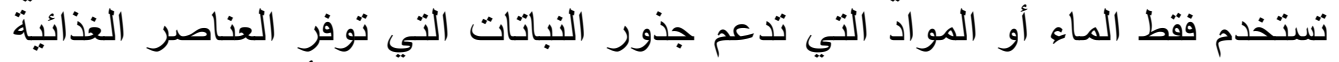

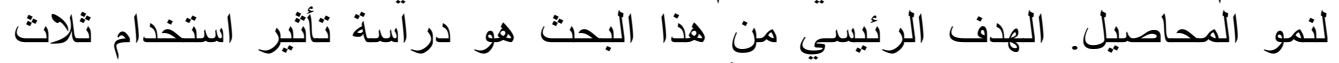

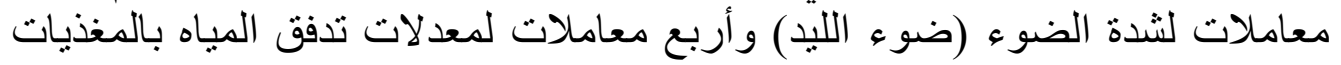

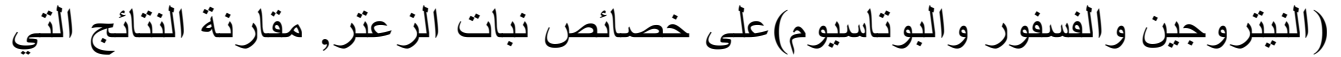

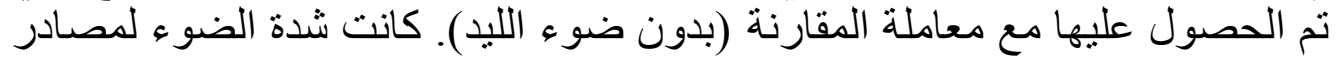

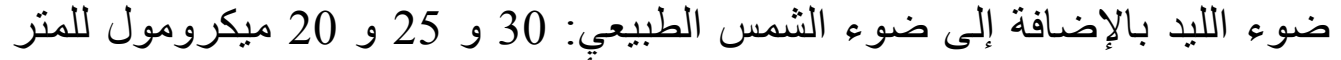

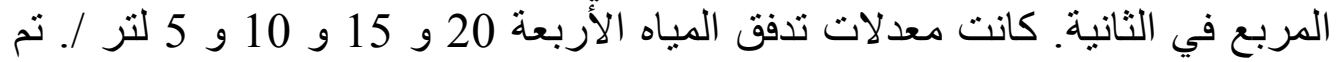

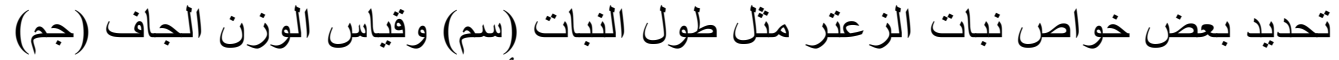

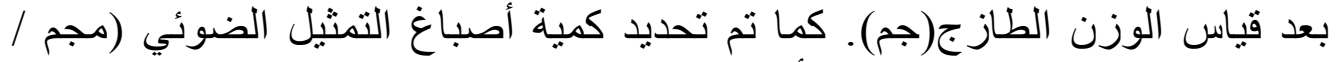
جم) وتر اكم الزيت العطري في الأور اق (\%) (ب). أظهرت النتائج التجريبية أن أعلى قيم سجلت في نمو نبات النات الزعتر لكل من

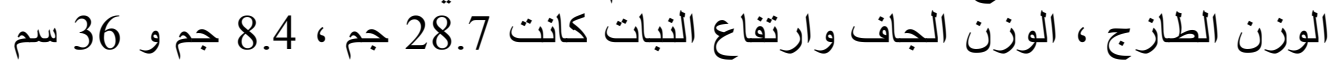

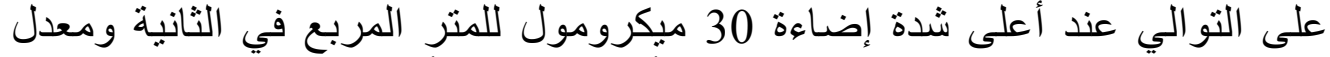

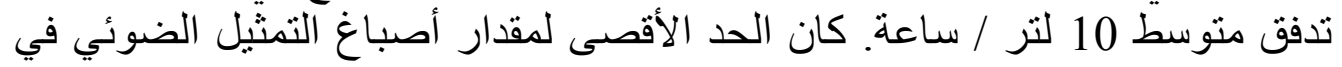




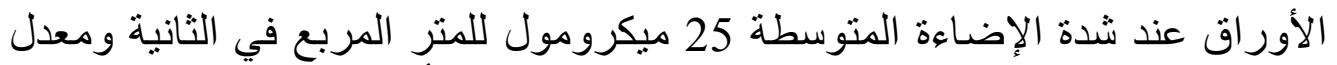

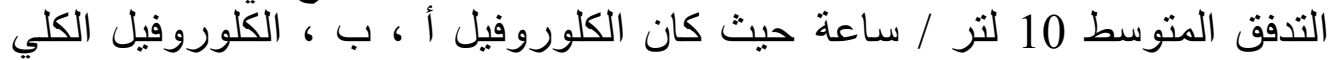

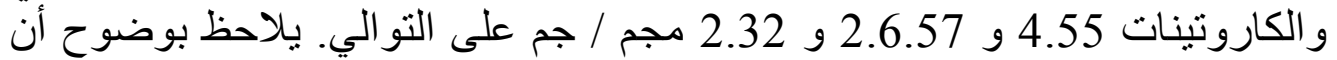

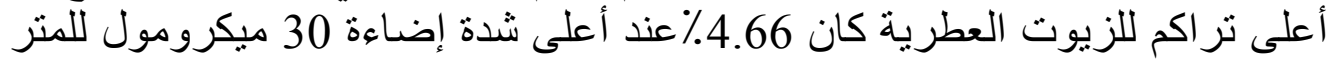

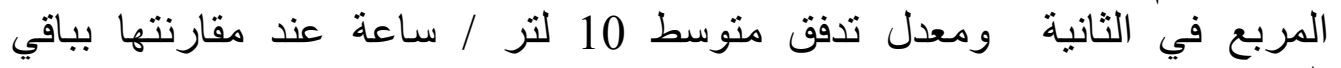

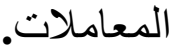
التوصية:

يوصى بإستخدام شدة الإضـاءة ومعدلات تدفق المياه لزيادة إنتاجية وحدة الزراعة

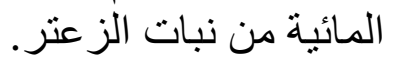

